\title{
Tradisi Hafalan Qur'an di Masyarakat Muslim Indonesia
}

\author{
Ali Romdhoni ${ }^{1}$
}

\begin{abstract}
This article aims to show how far the system of memorization of the Qur'an is still needed and has its own contribution in preserving the originality of the Qur'an. Modern tools and media which can record the authenticity of the Qur'an, such as symbol (through writing) and sound (cassette and CD) have some limitations. These medias are passive, and could not select the valid data from manipulated data. Human memory, on the other hand, is active and can fix the error of the text. This modern technology, however, is very beneficial to ease the need in Qur'anic studies.

Using ethnographical approach, this research proves that the tradition of Qur'anic memorization can be divided into three purposes: first, for pure ritual orientation, second, for Islamic studies, and third for preserving the originality of the Qur'an.
\end{abstract}

\begin{abstract}
Abstrak
Tulisan ini ingin menunjukkan sejauh mana sistem hafalan tetap diperlukan dan memiliki wilayah tersendiri dalam menjaga kemurnian al-Qur'an. Alat modern yang memiliki kemampuan merekam keotentikan wahyu al-Qur'an baik dalam bentuk simbol (tulisan) maupun suara (pita kaset dan kepingan CD) dalam batasbatas tertentu memiliki kelemahan. Piranti ini bersifat pasif, tidak memiliki kemampuan menyeleksi manipulasi data, sementara memori ingatan manusia bersifat aktif, bisa bekerja menyeleksi apabila ada kesalahan naskah. Meskipun demikian, teknologi semacam ini jelas akan sangat bermanfaat mempermudah kebutuhan kajian kequr'anan.

Dengan metode etnografi, penelitian ini menunjukkan bahwa tradisi hafalan Qur'an bisa dipilah menjadi tiga macam. Pertama, menghafal al-Qur'an dengan orientasi murni ibadah, kedua, untuk kajian keislaman, dan ketiga, memelihara kemurnian al-Qur'an.
\end{abstract}

Keywords: hịž al-Qur’ān, jam ‘ al-Qur'an, illiterate.

${ }^{1}$ Dosen Fakultas Agama Islam Universitas Wahid Hasyim Semarang. E-mail: ali_romdhoni@yahoo.com 


\section{Pendahuluan}

Dalam disiplin Ulumul Qur'an, proses perekaman wahyu (jam' al-Qur'ân) digolongkan menjadi dua kategori, yaitu: jam' al-Qur'ân dalam arti menghafal, dan menulis al-Qur'an. Masing-masing kategori memiliki wilayah kerja tersendiri. Jam' al-Qur'ân dalam arti menghafal, misalnya, merekam dan menjaga al-Qur'an dari kepunahan dengan mengingat (menyimpan) dalam hati dan fikiran. Sementara jam' al-Qur'ân dalam arti menulis adalah melahirkan keseluruhan ayat-ayat al-Qur'an dalam bentuk tulisan, sehingga wahyu yang turun bisa dijumpai dalam bentuk verbalnya.

Hingga saat ini aktifitas menghafal dan menulis (mencetak mushaf) alQur'an terus berlangsung. Bahkan bisa dikatakan semakin mapan. Di negaranegara yang berpenduduk muslim di berbagai belahan dunia bisa dijumpai pusat pendidikan keislaman dengan kegiatan utama menghafal al-Qur'an. Di sini, menghafal tidak lagi dilihat sebagai cara atau tahapan untuk memahami pesan wahyu, tetapi sudah menjadi paradigma keilmuan, bahkan tujuan. Di sisi lain, ada sebagian umat Islam yang memanfaatkan teks al-Qur'an untuk mendalami dan mengkaji secara kritis wahyu Tuhan itu.

Pertanyaannya, sejauh mana model hafalan al-Qur'an dan kajian teks alQur'an relevan untuk merekam wahyu dan sebagai proses pendidikan keislaman saat ini? Sistem hafalan dibutuhkan pada masa awal turunnya Islam akan tetapi apakah tetap efektif hingga hari ini? Adakah sistem lain yang lebih baik dan menggantikan model hafalan, mengingat perkembangan zaman terjadi begitu cepat sehingga memungkinkan ditemukan teknologi yang lebih canggih, termasuk dalam hubungannya dengan perekaman wahyu Tuhan.

Ada yang menyatakan tidak diperlukannya lagi hafal al-Qur'an dengan motivasi untuk mempertahankan eksistensi dan kemurnian al-Qur'an, atau bagi para pengkaji ilmu keislaman, terutama tafsir dan Ulumul Qur'an. Artinya, menghafalkan al-Qur'an paling tepat karena motivasi ibadah semata. Ungkapan seperti ini didasari pemikiran karena sudah begitu banyaknya ditemukan metode dan teknologi canggih sebagai sistem untuk merekam ayat-ayat al-Qur'an. Baik dalam bentuk lisan atau pun dalam wujud suara, seperti pita kaset, kepingan compact disc (CD), komputer dan lain sebagainya. Selain itu, hari ini juga sudah tersedia berbagai ensiklopedi dan indeks seputar al-Qur'an.

Tulisan ini bermaksud menjawab bagaimana urgensi menghafal al-Qur'an bagi para akademisi dan bagi kaum muslim, utamanya di Indonesia dalam suasana yang sudah sangat maju seperti sekarang ini. Tulisan ini juga ingin menunjukkan sejauh mana sistem hafalan tetap diperlukan dan memiliki wilayah tersendiri dalam menjaga kemurnian al-Qur'an. 
Penulis memilih teori etnografi untuk menceritakan dan menelusuri objek kajian. Etnografi merupakan kajian tentang kehidupan dan kebudayaan suatu masyarakat atau etnik, misalnya tentang adat-istiadat, kebiasaan, hukum, seni, religi, bahasa. Etnografi merupakan kegiatan peneliti untuk memahami cara orang-orang berinteraksi dan bekerjasama melalui fenomena teramati kehidupan sehari-hari. Bisa juga dipahami bahwa etnografi adalah pelukisan yang sistematis dan analisis suatu kebudayaan kelompok, masyarakat atau suku bangsa yang dihimpun dari lokasi objek kajian dalam satu kurun waktu. ${ }^{2}$

Fenomena menghafal Qur'an di lingkungan masyarakat muslim Indonesia merupakan aktifitas satu kelompok manusia yang meliputi cara berfikir, berinteraksi dan bekerjasama dalam kehidupan sehari-hari. Di sini, penulis melakukan pengamatan, analisis, dan pengambilan kesimpulan di lapangan. Selain itu juga mengkaji kumpulan literatur yang menghimpun jejak aktifitas kaum penghafal Qur'an.

Akhirnya, tulisan ini adalah pelukisan yang sistematis dan analitis atas suatu kebudayaan kelompok, masyarakat muslim penghafal Qur'an di Indonesia, yang dihimpun dari lapangan dalam satu kurun waktu.

\section{Sistem Memorisasi dan Masyarakat Niraksara}

A. Teeuw dalam bukunya, Indonesia: Antara Kelisanan dan Keberaksaraan menceritakan hasil riset lapangan tentang sistem memorisasi dan masyarakat niraksara (buta huruf) yang dilakukan di berbagai kawasan di dunia, termasuk di Asia Tenggara. Hasil penelitian itu menyimpulkan, dalam masyarakat illiterate (buta huruf) akan sangat sulit terjadi penghafalan karya yang panjang. Kesimpulan ini sekaligus membantah anggapan yang mengatakan bahwa dalam masyarakat yang tidak mempunyai tulisan, satu-satunya jalan untuk mengamankan ciptaan lisan adalah melalui penghafalan. Pasalnya,

${ }^{2}$ Etnografi adalah kajian tentang kehidupan dan kebudayaan suatu masyarakat atau etnik. Koentjaraningrat menjelaskan, kaum kolonial ini mencatat semua fenomena (yang menurut mereka) menarik yang dijumpai selama perjalanannya, antara lain berisi tentang adat istiadat, susunan masyarakat, bahasa dan ciri-ciri fisik dari suku-suku bangsa. Etnografi yang akarnya antropologi pada dasarnya merupakan kegiatan peneliti untuk memahami cara orang-orang berinteraksi dan bekerjasama melalui fenomena teramati kehidupan sehari-hari. Dengan demikian, etnogarafi adalah pelukisan yang sistematis dan analisis suatu kebudayaan kelompok, masyarakat atau suku bangsa yang dihimpun dari lapangan dalam kurun waktu yang sama. Koentjaraningrat, Pengantar Ilmu Antropologi (Jakarta: Rineka Cipta, 2009), 57. 
masyarakat yang tidak mengenal tulisan tidak mungkin bisa mengulang secara persis teks-teks yang telah dihafalkan. ${ }^{3}$

Dalam kasus tukang cerita, misalnya, setiap kali berpentas membawakan puisi naratif lisannya, dia akan menciptakan kembali puisi-puisinya secara baru dan spontan beserta gubahan-gubahannya. Artinya, di sini si tukang cerita sebenarnya tidak bisa mengingat secara persis puisi-puisinya, karena itu, setiap kali tampil akan terjadi penambahan atau pengurangan - berimprovisasi.

Lebih lanjut menurut Jack Goody, pada orang-orang yang tidak mengenal tulisan tidak terjadi sistem memorisasi otak (ingatan). Pernyataan antropolog Goody ini didasarkan pada pengamatannya terhadap masyarakat Barat dan Afrika Barat. ${ }^{4}$ Ternyata memorisasi dalam kebudayaan lisan sangat jarang terjadi. Secara umum dalam masyarakat-masyarakat sederhana, pengulangan yang tepat dari bahasa yang baku, baik bersifat naratif atau tidak, panjang atau pendek, hampir tidak pernah terjadi. Memorisasi justru merupakan gejala yang khusus terikat pada kebudayaan yang sudah mengenal tulisan.

Goody kemudian menguatkan pendapatnya dengan menyuguhkan empat alasan. Pertama, teknik memorisasi baru dimungkinkan oleh adanya teks tertulis yang menjadi pegangan dan norma untuk penghafalan teks yang dianggap penting oleh si penghafal, sementara dalam masyarakat lisan tidak ada teks yang baku yang dapat dihafalkan secara exact (persis). Kedua, baru dalam masyarakat yang mengenal naskah mulai ada sekolah, sementara sekolah menjadi tempat mempelajari ilmu pengetahuan (termasuk baca-tulis) serta mengembangkan teknik memorisasi berdasarkan teks tertulis. Ketiga, baru melalui tulisan, hasil pengetahuan dapat disusun kembali secara sistematis sehingga mudah dihafalkan, misalnya melalui daftar, tabel, serta tata bahasa. Keempat, melalui tulisan akan terjadi kemungkinan visualisasi dan penghafalan lewat mata. Melalui penglihatan, proses penghafalan akan terasa lebih gampang ketimbang melalui pendengaran. Atau, paling tidak, dengan melihat teks yang akan dihafalkan akan dapat memperkuat kesanggupan mental untuk menghafalkannya. Yang terpenting lagi, melalui teks tertulis akan terjadi memorisasi, penyalinan naskah secara harfiah (copying). ${ }^{5}$

${ }^{3}$ Tidak adanya rujukan yang baku dalam hafalan tertentu bisa memunculkan beragam versi teks yang berasal dari hafalan yang sama. A. Teeuw, Indonesia: Antara Kelisanan dan Keberaksaraan (Jakarta: Pustaka Jaya, 1994), 4-5.

${ }^{4}$ Jack Goody, The Interface Between the Written and the Oral (Cambridge: Cambridge University Press, 1987), 177, dikutip oleh A. Teeuw, Indonesia: Antara Kelisanan dan Keberaksaraan, 7.

${ }^{5}$ A. Teeuw, Indonesia: Antara Kelisanan dan Keberaksaraan, 4-7. 
Di sisi lain, terdapat ribuan umat Islam yang memiliki kekuatan ingatan dan ketepatan dalam menghafal ayat demi ayat al-Qur'an bukan dengan membaca atau melihat sebelumnya, tetapi murni dari mendengarkan-karena keterbatasan penglihatan. Adalah fakta, bahwa di berbagai belahan dunia Islam, termasuk di Indonesia, banyak bisa dijumpai para penghafal mushaf al-Qur'an yang memiliki keterbatasan dalam penglihatan. Yang jelas, kemampuan mereka dalam melantunkan bait demi bait ayat-ayat Tuhan tidak kalah teliti bila dibanding dengan para penghafal lain yang memiliki kesempurnaan penglihatan. Bahkan di antara mereka ada yang lebih unggul. Hal ini tentu menjadi catatan tersendiri.

Namun demikian, kesimpulan Goody tetap bisa dimengerti, mengingat fenomena maraknya umat Islam yang menghafal al-Qur'an dengan tanpa melihat teks adalah pengecualian. Meskipun mereka menghafal dengan tidak berpegang pada teks, tetapi di sekeliling mereka bisa dijumpai banyak sekali orang yang mengerti bacaan al-Qur'an yang benar, sehingga apabila mereka melakukan kesalahan bisa dengan mudah dibenarkan orang lain. Kondisi inilah yang dimaksud Goody dengan bahasa "teks baku".

Data sejarah menginformasikan, ketika wahyu (al-Qur'an) disampaikan kepada Nabi Muhammad s.a.w., seketika itu juga Nabi memerintahkan para sahabat (yang menguasai sistem baca-tulis Arab dengan baik) untuk mengabadikan wahyu (al-Qur'an) dalam bentuk tulisan. ${ }^{6}$ Al-Zarqânî menulis, pada masa-masa turunnya al-Qur'an, Nabi s.a.w. dikelilingi para penulis wahyu yang handal - para sekretaris Nabi. Apabila turun wahyu dari Allah, segera Nabi memanggil beberapa dari mereka. Para sahabat pilihan itu adalah al-Khulafâ' alRâshidûn, Mu'âwiyah, Abân bin Sa'îd, Khâlid bin Walîd, Ubay bin Ka’b, Zaid bin Thâbit, Thâbit bin Qais, Arqam bin Ubay, dan Hanzhalah bin al-Rabî’?

Begitu besar dan pentingnya kodifikasi al-Qur'an, sehingga ia tidak selesai dalam sekali tempo. Ia menjadi agenda program besar umat Islam, yang melibatkan beberapa generasi di masa pertumbuhan Islam. Kodifikasi periode pertama dimulai pada masa Rasulullah, kemudian ditindaklanjuti kodifikasi periode kedua pada masa kekhalifahan Abû Bakar (memerintah 11-13 H/ 632$634 \mathrm{M})$, dan kodifikasi periode ketiga terjadi pada masa pemerintahan 'Uthmân

\footnotetext{
${ }^{6}$ Segera setelah wahyu pertama turun Nabi memerintahkan para sahabat yang bisa membaca dan menulis untuk mengabadikan al-Qur'an dalam bentuk tulisan (teks) selain juga dengan menghafalkannya. Proses ini terus berkelanjutan hingga peristiwa turunnya wahu terakhir. Untuk proses penulisan dan penghafalan (jam') al-Qur'an. AlZarkashi, al-Burhân, 170.

${ }^{7}$ Baca al-Zarqânî, Manâhil al- 'Irfần, juz 1, 368.
} 
bin 'Affân (memerintah 24-36 H/ 644-656 M). Ketiga generasi ini secara estafet saling melanjutkan dan menyempurnakan program kodifikasi al-Qur'an. ${ }^{8}$

Nabi Muhammad s.a.w. memantau dan mengawal secara langsung proses penulisan ayat al-Qur'an, begitu juga dengan proses penyusunan ayat-ayat dan surah al-Qur'an. Ayat yang sudah dicatat kemudian disimpan di rumah Nabi, sementara para pencatat juga membawa salinannya untuk arsip (koleksi) mereka pribadi. ${ }^{9}$ Dengan model begini akan ada kontrol antara koleksi para pencatat dan suhuf yang tersimpan di kediaman Nabi Muhammad s.a.w. Di luar itu, masih ada kontrol dari kalangan penghafal al-Qur'an (kelompok sahabat).

Tindakan Nabi Muhammad s.a.w. ini bisa dimaknai, bahwa reproduksi teks secara exact (persis) akan membutuhkan teks tertulis sebagai sumber utama untuk proses memorisasi. Karena itu, ketika itu juga Nabi memerintahkan untuk mendokumentasikan wahyu dalam bentuk tulisan. Maka sejak itu, sistem hafalan dan tulisan saling memperkuat dalam menjaga keutuhan dokumentasi wahyu. Dengan demikian, kesimpulan Goody masih relevan dalam konteks ini. Perintah Nabi ini tentu terkait dengan kepentingan umat Islam di masa-masa yang akan datang, yaitu untuk mempelajari dan menjaga al-Qur'an.

Tidak hanya dalam kasus al-Qur'an. Sistem seperti ini juga terjadi dalam kebudayaan Hindu dengan Weda sebagai kitab suci, yang mana sistem memorisasi yang kuat dikembangkan atas dasar tulisan. Tata bahasa Sanskerta gubahan Panini yang sangat menunjang teknik penghafalan Weda yang amat canggih di kalangan umat Brahmana tidak mungkin diciptakan tanpa pemakaian simbol tulisan. ${ }^{10}$

Dari uraian paragraf di atas bisa disimpulkan, sistem hafalan dan tulisan mushaf al-Qur'an akan saling membantu dan melengkapi dalam mendokumentasikan sebuah data (informasi) sehingga tidak mengalami reduksi yang berarti. Begitu pula dalam konteks al-Qur'an. Namun demikian, sampai di sini masalah belum selesai. Tugas utama adalah mengkaji wahyu-yang sudah terdokumentasikan, baik berupa tulisan mushaf maupun yang tersimpan dalam

${ }^{8}$ Al-Zarkashi, al-Burhân, 164-171. Baca juga al-Shâlih, Mabâhith, 65-89; alZarqânî, Manâhil al- 'Irfần, juz 1, 246. Lihat juga Muhammad 'Ali al-Șâbûnî, al-Tibyân fî Ulûm al-Qur'ân (Beirut: 'Âlim al-Kutub, cetakan pertama, 1985), 49-61.

9 Tidak heran, ketika kelak 'Uthmân bermaksud menyeragamkan mushaf alQur'an, beberapa sahabat diketahui memiliki mushaf koleksi sendiri. Namun, mushafmushaf ini diminta oleh 'Uthmân, untuk menghindari munculnya (potensi) konflik dan perbedaan di tubuh umat Islam. Baca al-Zarqânî, Manâhil al-'Irfần, juz 1, 260.

${ }^{10}$ Jack Goody, The Interface Between the Written and the Oral, 110-122, dikutip oleh A. Teeuw, Indonesia: Antara Kelisanan dan Keberaksaraan, 7. 
hati dan fikiran - itu sendiri, sehingga pesannya bisa dimengerti oleh umat manusia.

\section{Masyarakat Arab Sebelum al-Qur'an Turun: Illiterate}

Bila dibandingkan dengan bangsa-bangsa di sekitarnya, seperti Mesir, Babilonia, atau China, bangsa Arab bisa dikatakan terlambat dalam hal bacatulis. $^{11}$ Keterlambatan ini disebabkan oleh kecenderungan kehidupan bangsa Arab itu sendiri. Menurut cerita, pada masa sebelum Islam mayoritas bangsa $\mathrm{Arab}^{12}$ dikenal memiliki tabiat-tabiat kurang mendukung bagi tumbuhnya tradisi baca-tulis. Tabiat-tabiat itu, misalnya: Pertama, masyarakat Arab zaman dulu hidup secara nomad (berpindah-pindah) dari satu kawasan ke kawasan lain dengan berbagai tujuan, seperti untuk mencari lahan yang subur, ${ }^{13}$ atau menjauhi kemungkinan datangnya serangan musuh dari suku lain. ${ }^{14}$ Kebiasaan berpindah-pindah ini membuat mereka tidak memiliki kesempatan untuk membangun kebudayaan yang mapan, seperti budaya membaca dan menulis (intelektualitas).

Memang ada sebagian masyarakat Arab yang hidup menetap di suatu kawasan tertentu, tetapi jumlah mereka sangat sedikit. Contoh dari komunitas Arab yang hidup secara menetap adalah suku Quraisy. Mereka membentuk aliansi perdagangan di Mekah. ${ }^{15}$ Menurut penuturan Bernard Lewis, sudah sejak lama sebelum datangnya Islam, kota Mekah telah dihuni oleh suku Quraisy dari Arab Utara. Banyak di antara mereka yang hidup dengan berdagang. Bahkan sudagar-saudagar Quraisy telah membuat sindikat perdagangan lintas negara. Mereka membuat kontrak perdagangan dengan para penguasa di Byzantium, Abyssinia (Etiophia), dan negara-negara perbatasan Persia. Dalam rentang

${ }^{11}$ Yasin Hamid Safadi, Islamic Calligraphy (London: Themes and Hudson, 1978), 7. Baca juga D. Sirojuddin AR., Seni Kaligrafi Islam (Jakarta: PT. Multi Kreasi Singgasana, 1992), 18.

12 Bangsa Arab merupakan masyarakat kecil yang dibangun berdasarkan ikatan keluarga, keturunan (nasab) kekerabatan, dan ikatan etnis, masyarakat pertanian dan perkotaan, perekonomian pasar, kepercayaan monotheistik, dan imperium birokratis. Baca Ira M. Lapidus, A History of Islamic Societies, second edition (Cambridge: Cambridge University Press, 2002), 3.

${ }_{13}$ Perpindahan mereka dari satu tempat ke tempat yang lain itu mengikuti tumbuhnya stepa atau padang ruput yang tumbuh secara sporadis di tanah Arab di sekitar oasis (genangan air) setelah turun hujan. Rumput-rumput ini sangat dibutuhkan masyarakat untuk menghidupi domba-domba, binatang unggulan mereka. Ali Mufrodi, Islam di Kawasan Kebudayaan Arab (Jakarta: Logos, 1997), 5.

${ }^{14}$ Philip K. Hitti, History of The Arabs (London: Macmillan Education, 1970), tenth edition, 20.

${ }^{15}$ W. Montgomery Watt, Pengantar Studi Al-Qur'an: Penyempurnaan atas Karya Richard Bell, terj. Taufik Adnan Amal, cetakan I (Jakarta: CV. Rajawali, 1991), 98. 
waktu yang sangat lama, komunitas pedagang (saudagar) dari suku Quraisy terus memimpin aliansi perdagangan itu. ${ }^{16}$

Kedua, masyarakat Arab hidup bersuku-suku dengan rasa fanatisme kesukuan (chauvinisme; 'asabiyyah) yang sangat kental. Antara satu suku dengan suku lainnya sering terjadi persaingan yang sangat ketat. Tidak jarang mereka terlibat dalam pertikaian, saling membanggakan kelompok dan keturunannya masing-masing sembari merendahkan kelompok dan keturunan yang lain. ${ }^{17}$ Dalam kondisi seperti ini, hampir bisa dipastikan, peperangan selalu menjadi penyelesaian akhir, bahkan peperangan bisa berlarut-larut hingga bertahun-tahun. ${ }^{18}$ Oleh karena itu, muncul istilah yang sangat masyhur untuk menyebut perang berkepanjangan yang melibatkan kabilah-kabilah Arab, yaitu Ayyâmu al-'Arab.

Di antara sekian banyak perang antar kabilah-kabilah Arab yang pernah terjadi, ada perang yang sangat masyhur dan dikenang oleh masyarakat Arab, yaitu: pertama, Perang al-Basûs. Perang ini terjadi sebelum Islam lahir dan berlangsung selama empat puluh tahun. Yang terlibat dalam perang ini adalah Kabilah Bakr dan Taghlib-keduanya keturunan Wail. Menurut cerita, terjadinya perang ini dipicu oleh binatang unta milik al-Basûs, seorang perempuan tua dari Kabilah Bakr. Gara-gara salah satu personil Kabilah Taghlib melukai unta ini, dua suku akhirnya terlibat pertempuran dalam waktu yang cukup lama. ${ }^{19}$ Kedua, Perang Dahîs dan al-Ghubarâ'. Perang ini terjadi antara 'Abasa dan Dzubiyan-keduanya adalah putera Baghid bin Raith bin Ghathavan. Perang ini terjadi karena taruhan pacuan kuda yang diadakan oleh Qais bin Zuhair dan Haml bin Badr bin Raith. Perang ini berlangsung dalam waktu kurang lebih empat puluh tahun. Ketiga, Ayyâm al-Fijâr. Ayyâm al-Fijâr adalah peperangan yang terjadi pada bulan-bulan suci antara kabilah-kabilah yang berdiam di tanah Hijaz. al-Fijâr I terjadi antara Kinanah dan Hawazan. Peristiwa ini tidak menimbulkan korban yang serius. Al-Fijâr II terjadi antara Kabilah Quraisy dengan Hawazan. Pada peristiwa ini kedua belah pihak yang bertikai bisa didamaikan oleh Harb bin Uyamah. Al-Fijâr III terjadi antara Kinanah dengan Hawazan. Al-Fijâr IV terjadi antara Quraisy bersekutu dengan

${ }^{16}$ Baca Bernard Lewis, The Arabs in History, cet. $1^{\text {st }}$ (New York: Harper Torchbooks, 1960), 23.

${ }^{17}$ Abî 'Umar Ahmad ibn Muhammad ibn 'Abd Rabbih al-Andalusî, al-'Iq alFarîd, juz 3 (Beirut: Dâr al-Kitâb al-'Arabî, 1973), 313.

18 Ja'far Subhani, al-Risalah: Sejarah Kehidupan Rasulullah, terj. Muhammad Hasyim dan Meth Kierana, cetakan ke-1 (Jakarta: Lentera, 1996). 12.

19 Perang al-Basûs diceritakan secara detail oleh Hasan Ibrahim Hasan dalam bukunya, Sejarah dan Kebudayaan Islam, terj. A. Bahauddin (Jakarta: Kalam Mulia, 2006), 90 . 
Kinanah melawan Hawazan. Perang al-Fijâr IV ini merupakan yang terbesar di antara keempat perang al-Fijâr yang pernah terjadi. ${ }^{20}$ Perang ini terjadi pada tahun kedua puluh enam sebelum kerasulan Nabi Muhammad (yaitu ketika Rasulillah berusia empat belas tahun). ${ }^{21}$

Masyarakat Arab dengan struktur sosial yang demikian kacau dan cenderung bersinggungan dengan komunitas di sekitarnya tentu akan kesulitan untuk mendirikan suatu komunitas bersama yang bersatu dan melembaga. Tidak adanya stabilitas keamanan ini juga membuat masyarakat ini tidak memiliki waktu untuk membangun tradisi intelektual, termasuk mempelajari sistem bacatulis. Bisa dikatakan, pada masa-masa (sebelum Islam) ini tulisan masih menjadi sesuatu yang langka. Kepandaian menulis hanya dikuasai beberapa orang, yaitu para bangsawan dan tokoh spiritual (misalnya, tukang ramal atau dukun), bahkan, masyarakat umum masih menganggapnya sebagai suatu yang ajaib dan supranatural - sesuatu yang mengagumkan. Baru kemudian ketika Islam lahir, Nabi Muhammad atas petunjuk al-Qur'an mempelopori pengenalan tulisan pada khalayak ramai (publik). ${ }^{22}$

Namun demikian, sebuah sumber mengatakan bahwa sejak 1000 tahun sebelum masehi (SM) sebuah tulisan jenis Musnad sudah berkembang di lingkungan masyarakat Arab kuno. Tulisan jenis Musnad, menurut al-Muqrizî, banyak dipakai oleh masyarakat Himyar dan raja-raja 'Âd. ${ }^{23}$ Namun, dugaan ini sulit dibuktikan karena tidak ada peninggalan sejarah yang bisa ditemukan. ${ }^{24}$ Bahkan pada masa-masa selanjutnya tulisan jenis Musnad harus ditinggalkan

${ }^{20}$ Peristiwa-peristiwa perang ini disebut al-Fijâr karena terjadi pada bulan-bulan suci, yaitu bulan-bulan yang dinyatakan haram melakukan perang, tetapi masyarakat Arab melanggar ketentuan itu. Hasan, Sejarah dan Kebudayaan Islam, 100-108.

${ }^{21}$ Bahkan sebuah riwayat menyebutkan, Nabi sendiri terlibat dalam peperangan tersebut bersama paman-pamannya.

${ }^{22}$ Ini merupakan praktik yang lazim dalam budaya yang terutama bersifat lisan. Sajak-sajak Arab zaman pra-Islam juga disimpan dalam ingatan. W. Montgomery Watt, Richard Bell: Pengantar al-Qur'an, terj. Lillian D. Tedjasudhana (Jakarta: INIS, 1998), 27.

${ }^{23}$ Menurut para ahli tulisan Arab merupakan pecahan dari akar tulisan Suryanî. Pendapat ini didasarkan pada kemiripan bentuk huruf-huruf Arab dengan huruf-huruf Suryanî. Habîbullâh Faḍâ'ilî, Ațlas al-Khațt wal-Khuțût, cetakan ke-1 (Siria: Dar Thalas lid Dirasat wal Tarjamah wan Nashr, 1993), 10. Baca juga Ilham Khoiri R, Al-Qur'an dan Kaligrafi Arab (Jakarta: Logos, 1999), 52. Pendapat lain mengatakan, bahwa alfabet Arab sebelum Islam lahir dari tulisan Funisia. Tetapi ada juga pendapat yang meyakini bahwa tulisan Arab dan Kan'an tumbuh bersamaan di kepingan Jazirah Sinai. Di tempat ini pada tahun 1904-1905 ditemukan beberapa ukiran bertuliskan huruf-huruf yang mendekati bentuk tulisan Mesir Hierogliph. Lihat Kâmil al-Bâbâ, Rûh al-Khatṭ al'Arabî, cetakan pertama (Beirut: Dâr al-'Ilm wa al-Malâyîn, 1983), 21.

24 D. Sirojuddin AR., Seni Kaligrafi Islam, 26-27. Baca juga Ibn Khaldûn, Muqaddimah (Kairo: Musțafâ Muhammad, t.th.), 418. 
penggunanya karena munculnya tulisan jenis lain, yaitu Kindi dan Nabtî. ${ }^{25}$ Tulisan jenis Nabtî inilah yang kemudian disebut-sebut sebagai bentuk tulisan Arab paling awal. Tulisan jenis ini dipakai oleh suku Nabṭ̂, ras Arab yang mendiami wilayah utara Jazirah Arabia di negeri Yordan dengan pusat pemerintahannya di kota Puerto pada abad $1 \mathrm{SM}^{26}$

Keterangan dalam The Encyclopaedia of Islam $^{27}$ memberikan informasi yang lebih jelas lagi, bahwa bukti arkeologis menunjukkan suatu bentuk tulisan sudah dikenal di Arabia selama berabad-abad. Selain diketemukan sebuah prasasti dalam bahasa Arab selatan yang umurnya, diduga, sebelum era Kristen, juga diketemukan sebuah prasasti di Arabia barat-laut dalam abjad Nabataea, Lihyânî dan Samûdî yang diduga dibuat pada abad-abad sebelum munculnya Nabi Muhammad. Untuk bahasa Arab klasik dan tulisan Arab, peninggalan paling awal adalah tiga grafiti yang terdapat pada dinding sebuah kuil di Suriah, yang bertanggal kira-kira 300 SM, sementara empat prasasti Kristen yang ditemukan termasuk abad keenam. Tetapi, yang jelas belum ditemukan prasasti awal (yang tingkat akurasi dan keotentikannya tidak bisa dibantah) di sekitar Mekah dan Madinah. ${ }^{28}$

Dengan demikian, bisa dikatakan bahwa masyarakat yang mendiami kawasan semenanjung Arabia sudah sejak lama (sekitar 1.600 tahun sebelum alQur'an turun) telah mengenal budaya baca-tulis. Namun pertanyaannya, sampai seberapa besar tulisan dimanfaatkan untuk membantu kebutuhan hidup manusia sehari-hari. Dengan kata lain, apakah tradisi baca-tulis sudah menjadi budaya

${ }^{25}$ Abdul Karim Husain, Khat, Seni Kaligrafi: Tuntunan Menulis Halus Huruf Arab (Kudus: Menara Kudus, t.th.), 7.

${ }^{26}$ Secara geografis wilayah Kerajaan Nabtî sangat strategis. Kerajaan ini pernah mengalami masa-masa kejayaan. Wilayahnya mengalami pemekaran, sehingga daerah kekuasaannya membentang luas dari Semenanjung Jazirah Arab hingga ke kawasan tetangga-tetangganya yang berada di sebelah utara. Anggapan ini diperkuat dengan bukti-bukti yang berwujud inskripsi pahatan purbakala. Lihat Kâmil al-Bâbâ, Rûh alKhatt al-'Arabî, 20-23. Baca juga W. Montgomery Watt, Pengantar Studi Al-Qur'an, 4647. Baca juga D. Sirojuddin AR., Seni Kaligrafi Islam, 32-37. Baca C. Israr, Dari Teks Klasik sampai ke Kaligrafi Arab (Jakarta: Yayasan Masagung, 1985), 37-38. Habîbullâh Faḍ̂a'ilî, Ațlas al-Khatt wal-Khut ût, 97-100.

27 "Arabiyya" dalam The Encyclopaedia of Islam, edisi kedua (Leiden dan London, 1960), dikutip oleh Watt, Richard Bell: Pengantar Al-Qur'an, 28.

${ }^{28}$ Untuk mengatakan bahwa di kedua tempat ini, Mekah dan Madinah, juga sangat dimungkinkan sudah memiliki tradisi baca-tulis, beberapa pakar mendasarkan pada argumen, bahwa kedua wilayah ini ramai dengan aktifitas perdagangannya. Masa masyarakat yang demikian, kecakapan baca-tulis hampir bisa dipastikan dikuasai banyak orang, yaitu untuk keperluan administrasi perniagaan. Baca Watt, Richard Bell: Pengantar Al-Qur'an, 28. 
kolektif atau hanya milik sebagian kecil dari masyarakat Arab; dalam hal apa saja sebuah sistem tulisan digunakan?

Yang jelas, masyarakat Arab kuno belum memanfaatkan tulisan untuk kebutuhan hidup sehari-hari secara maksimal. Hal ini juga diakui oleh Hasan Ibrahim Hasan. ${ }^{29}$ Menurut Hasan, ada dua faktor yang menyebabkan sejarah bangsa Arab kuno hampir tidak dikenal sama sekali. Pertama, karena tidak adanya kesatuan politik di wilayah itu. Masyarakat Arab adalah komunitas yang terdiri dari suku-suku yang hidupnya berpindah-pindah. Di antara mereka mudah berperang antara satu suku dengan suku yang lain. Yang lebih penting, mereka tidak memiliki kesatuan orientasi menjadi bangsa satu yang besar dan berdaulat secara politik.

Kedua, karena bangsa Arab tidak mengenal tulisan. Mayoritas dari mereka adalah orang-orang yang tidak bisa baca-tulis, sehingga berbagai peristiwa penting yang terjadi pada mereka tidak dibukukan kecuali pada akhir masa pemerintahan Amawi. Sebelum masa itu, berita tentang Arab hanya bersandar pada periwayatan yang disampaikan secara lisan. Ini mengecualikan kondisi masyarakat Arab yang berada di ujung selatan Jazirah Arab, seperti masyarakat Kerajaan Saba' dan Ma'in. Khusus untuk berita mengenai masyarakat di kedua wilayah ini bisa dilacak pada berbagai peninggalan mereka yang masih utuh dan terpelihara hingga sekarang.

Dengan kondisi yang demikian, bisa dipahami ketika sistem yang pertama kali digunakan untuk mengabadikan wahyu yang turun adalah hafalan, atau menyimpannya dalam hati dan fikiran. Namun demikian, kita juga mengetahui bahwa setelah itu Nabi segera memerintahkan para sahabat untuk menulisnya. Ini maknanya, Nabi juga melihat perlunya sistem tulisan dalam mengabadikan wahyu. Bukan berarti sistem hafalan kurang kokoh dalam memelihara wahyu, tetapi sistem hafalan adalah langkah paling efektif dan yang paling mungkin dalam kondisi saat itu. Untuk menyempurnakan kebutuhan umat Islam di masa yang akan datang, sistem hafalan harus didukung dengan adanya teks baku sebagai acuan.

Dari paragraf-paragraf di atas bisa disimpulkan, tradisi menghafal memang sudah tumbuh subur di kalangan masyarakat Nabi Muhammad bahkan sejak Islam belum ada. Tidak mengherankan, ketika wahyu turun, menghafal teks menjadi salah satu sistem yang digunakan untuk merekam al-Qur'an. Kegiatan menghafal al-Qur'an begitu diminati. Selain dalam ajaran agama Islam ritual ini dijanjikan pahala yang sangat besar, masyarakat yang melingkari Nabi sudah memiliki kebiasaan menghafal.

\footnotetext{
${ }^{29}$ Hasan, Sejarah dan Kebudayaan Islam, 1.
} 


\section{Proses Transformasi Pengetahuan}

Masyarakat Arab kuno tidak memiliki perhatian serius dalam hal pendidikan untuk anak-anak mereka. Tempat-tempat belajar juga masih sangat sulit ditemukan di wilayah Arab, termasuk di Mekah dan Madinah. Pendidikan yang berlangsung di lingkungan masyarakat Arab saat itu hanya berdasarkan kebutuhan mereka. Itu pun hanya bersifat ala kadarnya saja. Biasanya, anakanak mereka secara langsung diajari oleh para orang tuanya. ${ }^{30}$ Karena ini, mereka menjadi jauh dari akses ilmu pengetahuan yang berkembang secara luas saat itu. ${ }^{31}$

Masyarakat Arab kuno bahkan tidak memiliki budaya baca-tulis dan tidak menganggap catatan sebagai suatu hal yang penting. Model yang mereka pakai dalam menyimpan informasi adalah hafalan. Akibatnya, sejarah kehidupan masyarakat ini tidak terdokumentasi dengan baik dalam bentuk tulisan. $^{32}$ Sebagian besar dari masyarakat Arab merupakan orang-orang yang tidak tahu aksara (buta huruf). Kalau pun ada di antara mereka yang bisa menulis, jumlahnya sangat sedikit, biasanya adalah para pemuka masyarakat. Itu pun dianggap sebagai kekuatan supra-natural. ${ }^{33}$ Selain itu, dalam jumlah yang sangat sedikit, tulisan juga dipergunakan untuk kebutuhan perniagaan dan menulis puisi-puisi terbaik - yang biasanya kemudian digantungkan di Ka'bah (mu'allaqât). Kondisi ini menjadikan bangsa Arab mengandalkan hafalan, yang pada akhirnya menjadi tolok ukur kecerdasan dan kemampuan intelektual seseorang. ${ }^{34}$

Dalam hal ilmu politik, ekonomi, sosial, kedokteran dan lain-lain, bangsa Arab sangat ketinggalan bila dibandingkan dengan bangsa-bangsa lain di sekitarnya seperti Romawi dan Persia. Meski begitu, bangsa Arab memiliki kelebihan lain yang tidak dimiliki bangsa-bangsa lain di sekitarnya, misalnya: dalam bidang astronomi, meteorologi, arkeologi, sedikit tentang sejarah, nasab (asal-usul keturunan), pengobatan, perdukunan, serta bahasa dan sastra. ${ }^{35}$ Bahkan di bidang bahasa dan sastra, harus diakui, bahwa kemampuan mereka sangat cemerlang. Mereka memiliki perhatian yang sangat besar terhadap

${ }^{30}$ Hasan, Sejarah dan Kebudayaan Islam, 118.

31 Ahmad Amîn, Fajr al-Islâm, cetakan ke-11 (Dar al-Kutub, 1975), 3.

${ }^{32}$ Hasan Qâsim Habash al-Bayâtî, Riḥlah al-Muṣhaf al-Sharîf (Beirut: Dâr alQalam, 1414), 61. Lihat juga Muhammad Shukrî al-Alusî, Bulûgh al-Adâb fî Ma'rifah Aḥwāl al-'Arab, Vol. I (Beirut: Dâr al-Kut ûb al-'Ilmiyah, t.th.), 38.

33 M. M. Azami, Hadis Nabi dan Sejarah Kodifikasinya, terj. Ali Musthofa Ya'qub, cetakan ke-1 (Jakarta: Pustaka Firdaus, 1994), 75.

${ }^{34}$ M. Quraish Shihab, Mukjizat Al-Qur'an (Bandung: Mizan, 1998), 71.

${ }^{35}$ Quraish Shihab, Mukjizat Al-Qur'an, 72. 
bahasa dan keindahan sastra. Hal ini karena mereka memiliki perasaan halus dan ketajaman penilaian terhadap sesuatu. ${ }^{36}$

Khusus dalam bidang meteorologi, arkeologi, dan ilmu nasab, bisa dikatakan, bidang-bidang ini merupakan pengetahuan masyarakat Arab yang bersifat murni yang lahir karena dorongan lingkungan dan karakter negeri Arab itu sendiri. Tentang ilmu meteorologi, misalnya, tidak mengherankan bila pengetahuan ini dikuasai oleh masyarakat Arab, karena mereka mahir dalam mengikuti pergantian musim dan dalam mengenal waktu-waktu turun hujan. Kemudian ilmu arkeologi, mereka mahir dalam bidang ini karena masyarakat Arab secara khusus sudah menguasai pengetahuan tentang peninggalan (jejak) para pendahulu mereka. Hal ini didukung oleh kondisi alam padang gersang yang ditutupi oleh pasir yang mempermudah karakter mereka untuk menguasai ilmu tersebut. Selanjutnya, masyarakat Arab juga menguasai ilmu nasab. Hal ini karena jazirah Arab adalah daerah yang dihuni oleh bangsa yang komposisi penduduknya terdiri dari kabilah-kabilah yang tinggal saling berjauhan. Atas dasar ini, mereka sangat berhajat agar asal-usul mereka terpelihara sebagai sandaran dan tempat meminta bantuan - guna menjalin persekutuan atau guna menggalang kerja sama dalam melakukan suatu serangan kepada musuh-musuh mereka atau saat berlomba memperebutkan kursi kepemimpinan. ${ }^{37}$

Seperti itulah proses transformasi ilmu pengetahuan di antara orangorang Arab. Ia hanya terjadi dengan cara-cara yang sangat sederhana melalui tradisi lisan - pihak pertama menyampaikan secara lisan dan pihak kedua mendengarkan, untuk kemudian menghafalkannya. Bisa dipastikan, pada masamasa ini (sebelum Islam muncul) belum ada buku berbahasa Arab bisa dijumpai di jazirah Arab. Al-Qur'an adalah buku pertama berbahasa Arab. Al-Qur'an melalui wahyu pertamanya, iqra' (artinya, "Bacalah!") telah menjadi penanda dimulainya sebuah era baru: satu era di mana mencari ilmu pengetahuan adalah satu pekerjaan yang harus dilakukan oleh setiap orang. Era baru yang berarti bahwa setiap orang yang berilmu punya kewajiban untuk mengajar kepada orang lain. Ini terlihat, antara lain, beberapa saat setelah Nabi sampai di Madinah, segera dia menyediakan sarana belajar-mengajar dengan menyeru kepada para sahabat yang memenuhi kriteria terpelajar: ballighî 'annî walaw

${ }^{36}$ Yunus Ali al-Muhdar dan Bey Arifin, Sejarah Kesusastraan Arab, cetakan pertama (Surabaya: Bina Ilmu), 1983, 18.

${ }^{37}$ Di samping itu, masyarakat Arab juga menguasai ilmu-ilmu lain yang lahir karena dorongan kondisi alam padang pasir yang tandus dan gersang, yang lebih tepat disebut sebagai sejumlah pngetahuan ketimbang disebut sebagai ilmu-ilmu dengan makna seperti yang kita kenal dewasa ini. Hasan, Sejarah dan Kebudayaan Islam, 119120 . 
âyah. Era baru di mana penulisan ilmu pengetahuan (menulis buku) mulai dilakukan. Ini terlihat pada upaya Nabi yang mempekerjakan enam puluh penulis wahyu sebagai kado dalam memerangi kebodohan masyarakat kala itu. ${ }^{38}$

Menurut penulis, langkah Nabi dalam mengumpulkan para penulis handal, yang dari sana lahir satu komunitas pengkaji wahyu, adalah proses penciptaan lingkungan yang kondusif bagi kemungkinan terpeliharanya teks baku al-Qur'an. Hal ini sebagaimana diceritakan dalam kesimpulan kajian yang dilakukan Goody. Tanpa masyarakat ini, teks baku sebagai rujukan penghafal al-Qur'an sulit terwujud, kecuali pada diri Nabi. Akan tetapi Nabi mempertimbangkan kepentingan jangka panjang, dan demi kelestarian kajian ilmu-ilmu keislaman.

Di sini menunjukkan, masyarakat Arab sebelum turunnya al-Qur'an belum memanfaatkan membaca dan menulis untuk mengakses dan mengabadikan ilmu pengetahuan. Dalam kondisi yang demikian, kita bisa memaklumi kenapa untuk pertama-tama al-Qur'an diabadikan dengan hafalan; dan baru kemudian diabadikan dalam bentuk tulisan atas perintah Nabi Muhammad. Pada masa selanjutnya, antara model hafalan dan tulisan saling melengkapi dan menguatkan. Jelasnya, dalam sejarahnya al-Qur'an diabadikan dengan sistem hafalan dan tulisan.

\section{Tahfidz al-Qur'an: Antara Kajian, Ritual dan Orientasi Pembelajaran}

Hari ini kita menjumpai umat Islam, khususnya di Indonesia, begitu meminati dan mengagungkan al-Qur'an. Di antara ekspresi mencintai al-Qur'an adalah dengan menghafalnya. Karena itu, kita bisa menemukan pusat pendidikan yang secara khusus mencetak anak didiknya menjadi seorang hăfiż. Umumnya, pusat kegiatan semacam ini berada di pesantren-pesantren tradisional (pesantren huffāz). Sekedar menyebut, di Kudus, Jawa Tengah terdapat Pondok Tahfidz Yanbu'ul Qur'an, kemudian Pondok Tahfidz Qur'an BUQ Betengan Bintoro Demak, Pondok tahfidz di Tebu Ireng, Jombang, dan di berbagai wilayah di Indonesia.

Yang menarik, banyak di antara para penghafal al-Qur'an ini yang mendudukkan aktifitasnya (menghafal al-Qur'an) tidak lagi menjadi sarana untuk menggapai target setelahnya - tetapi telah menjadi tujuan itu sendiri. Penulis melakukan penelitian di beberapa lembaga pendidikan keislaman yang secara khusus mendisain anak-didik untuk menjadi seorang hạāiz. Hasilnya, mayoritas di antara mereka memposisikan menghafal al-Qur'an sebagai tujuan.

${ }^{38}$ Al-A'zami, Sejarah Teks Al-Qur'an, terj. Sohirin Solihin, dkk. (Jakarta: Gema Insani Press, 2005), 184. 
Fenomena ini menarik penulis untuk memetakan masyarakat peminat ('pengkaji') al-Qur'an, utamanya dengan mengaitkan fenomena banyaknya penghafal al-Qur'an di Indonesia. Pertama, pengkaji al-Qur'an yang memposisikan al-Qur'an sebagai teks yang mulia namun sekaligus memungkinkan dikaji secara kritis, untuk keperluan menggali kandungan maknanya. Kelompok ini mendudukkan aktifitas perekaman wahyu dalam hati dan fikiran sebagai proses untuk mencapai pemahaman ajaran Islam yang terkandung dalam al-Qur'an. Kelompok ini mengkaji al-Qur'an secara kritis, dan dalam batas-batas tertentu melakukan kritik. Mereka terus menggali dan mencari metodologi terbaru dalam memahami al-Qur'an, termasuk melibatkan teori-teori modern (sastra, bahasa, filsafat, sosiologi, dan lain-lain).

Kedua, pengkaji al-Qur'an yang memandang predikat 'hạāiz' sebagai prestasi tertinggi. Kelompok ini memposisikan hafal al-Qur'an sebagai tujuan, tidak lagi proses. Bagi kelompok ini, hafal Al-Qur'an adalah orientasi, target. Tidak ada target lagi setelah menghafal, karena tujuan akhir mereka adalah menghafal Al-Qur'an. Oleh karena itu, wacana yang berkembang di tengahtengah mereka adalah bagaimana teknik menghafal Al-Qur'an dengan cepat, memiliki hafalan yang kuat, dan lain sebagainya. Tidak terfikirkan oleh mereka, bagaimana metodologi pemahaman Al-Qur'an dalam rangka memecahkan persoalan kontemporer, dan lain sebagainya.

Berdasarkan penelusuran penulis, dalam kategori kedua ini juga terdapat tingkatan. Sebagian mereka menghafal dengan tanpa terlebih dahulu membekali diri dengan kemampuan makhraj yang baik. Mereka memiliki kemampuan bacatulis al-Qr'an kemudian memutuskan untuk menghafal al-Qur'an. Sebagian mereka memberi perhatian cukup terhadap pembelajaran makhraj, wakaf, washal (termasuk ilmu tajwid) sebelum melangkah pada aktifitas menghafal alQur'an. Sebagian lagi bahkan melengkapi kemampuannya pada qira'at sab'ah.

Ketiga, pengkaji al-Qur'an yang mendudukkan Al-Qur'an sebagai firman Allah, yang dengan membacanya akan menjadi bentuk ibadah (al-muta'abbad bitilāwatihi). ${ }^{39}$ Kelompok ini tidak mengkaji al-Qur'an secara kritis tetapi juga tidak menjadikan 'hafal al-Qur'an' sebagai orientasi. Motivasi utama mereka menghafal al-Qur'an adalah sebagai bentuk ibadah. Meskipun demikian, berdasarkan penuturan para penghafal al-Qur'an dalam kategori ini yang berhasil penulis temui, mereka rata-rata menuturkan memiliki pengalaman

${ }^{39}$ Al-Qur'ān huwa kalāmullāhi al-mu'jizu, al-munazzalu alā khātamil anbiyā'i wal mursalina, biwāsițati l-amīni Jibrīla alaihissalāmu al-maktūbu fil-muṣhafi, almanqūlu ilainā bi t-tawāturi, al-muta'abbadu bi tilāwatihi, al-mabdū'u bi sūrati 1fătiḥati, al-mukhtatamu bi sūrati al-nāsi. Baca pengertian al-Qur'an dalam Ali Ṣābūnī, al-Tibyan fi Ulumil Qur'an (Beirut: Alimul Kutub, t.th), 7. 
spiritual. Misalnya, ada sugesti positif akibat dari aktifitas menghafal al-Qur'an. Mereka merasa mudah dalam menyerap disiplin ilmu tertentu di luar kequr'anan. Pendeknya, dengan menghafal al-Qur'an mereka merasa 'tercerahkan'.

Dalam pandangan penulis, lembaga tahfidz al-Qur'an yang menjamur di Indonesia mayoritas adalah kategori kedua dan ketiga.

\section{Kesimpulan}

Hafalan al-Qur'an tetap relevan dan dibutuhkan bagi para pengkaji studi keislaman, bahkan hingga sekarang. Sistem hafalan diperlukan dan memiliki wilayah tersendiri yang tidak terjangkau sistem lain. Alat moderen yang memiliki kemampuan merekam keotentikan wahyu al-Qur'an baik dalam bentuk simbol (tulisan) maupun suara (pita kaset dan kepingan CD) dalam batas-batas tertentu memiliki kelemahan. Pasalnya, piranti ini bersifat pasif, tidak memiliki kemampuan menyeleksi manipulasi data. Sementara memori ingatan manusia bersifat aktif, bisa bekerja menyeleksi apabila ada kesalahan naskah. Meskipun, teknologi semacam ini jelas akan sangat bermanfaat mempermudah kebutuhan kajian kequr'anan. Dengan demikian, hafalan bisa dilihat dari tiga sisi. Pertama, menghafal al-Qur'an dengan orientasi murni ibadah, kedua, untuk kajian keislaman, dan ketiga, memelihara kemurnian alQur'an. Wallâh a 'lam bi al-ṣawâb.[]

\section{Daftar Pustaka}

Al-Qur'an al-Karim.

Amîn, Ahmad. Fajr al-Islâm. Cetakan ke-11. Dar al-Kutub, 1975.

al-Alusî, Muhammad Shukrî. Bulûgh al-Adâb fî̀ Ma'rifah Aḥ̂āl al-'Arâb. Vol.

I. Beirut: Dâr al-Kutûb al-'Ilmiyah, t.th.

Azami, M. M. Hadis Nabi dan Sejarah Kodifikasinya. Terj. Ali Musthofa Ya'qub. Cetakan ke-1. Jakarta: Pustaka Firdaus, 1994.

Al-A'zami, M. M.. Sejarah Teks Al-Qur'an. Terj. Sohirin Solihin, dkk. Jakarta: Gema Insani Press, 2005.

al-Bâbâ, Kâmil. Rûh al-Khatṭ al-'Arabî. Cetakan pertama. Beirut: Dâr al-'Ilm wa al-Malâyîn, 1983.

al-Bayâtî, Hasan Qâsim Habash. Rịhlah al-Muṣhạf al-Sharîf. Baerut: Dâr alQalam, 1414. 
Faḍ̂’ilî, Habîbullâh. Ațlas al-Khațt wal-Khututut, cetakan ke-1. Siria: Dar Ṭalas li al- Dirasat wa al- Tarjamah wa al-Nashr, 1993.

Goody, Jack. The Interface Between the Written and the Oral. Cambridge: Cambridge University Press, 1987.

Hasan, Hasan Ibrahim. Sejarah dan Kebudayaan Islam. Terj. A. Bahauddin. Jakarta: Kalam Mulia, 2006.

Hitti, Philip K. History of The Arabs, History of The Arabs. London: Macmillan Education, 1970. Tenth edition

Husain, Abdul Karim. Khat, Seni Kaligrafi: Tuntunan Menulis Halus Huruf Arab. Kudus: Menara Kudus, t.th.

ibn 'Abd Rabbih al-Andalusî, Abî 'Umar Ahmad ibn Muhammad. al-'Iq alFarîd. Baerut: Dâr al-Kitâb al-'Arabî, 1973.

Ibn Khaldûn, Muqaddimah. Mesir: Musthafâ Muhammad, t.th..

Israr, C. Dari Teks Klasik sampai ke Kaligrafi Arab. Jakarta: Yayasan Masagung, 1985.

Khoiri R, Ilham. Al-Qur'an dan Kaligrafi Arab. Jakarta: Logos, 1999.

Koentjaraningrat. Pengantar Ilmu Antropologi. Jakarta: Rineka Cipta, 2009.

Lapidus, Ira M. A History of Islamic Societies. Second edition. Cambridge: Cambridge University Press, 2002.

Lewis, Bernard. The Arabs in History. Cet. ${ }^{\text {st, }}$ New York: Harper Torchbooks, 1960

Mufrodi, Ali. Islam di Kawasan Kebudayaan Arab. Jakarta: Logos, 1997.

al-Muhdar, Yunus Ali dan Bey Arifin. Sejarah Kesusastraan Arab. Cetakan pertama. Surabaya: Bina Ilmu., 1983

Romdhoni, Ali. "Al-Qur'an dan Masyarakat Pembaca." Dalam Surat Kabar Mahasiswa Amanat, IAIN Walisongo Semarang. Edisi 109 AgustusSeptember 2007.

Romdhoni, Ali. “Al-Qur'an: Memerangi Illiteracy Mencipta Peradaban Ilmu Pengetahuan” Journal of Qur'an and Hadith Studies 1, 1 (2012).

Romdhoni, Ali. "Al-Qur'an dan Literasi Arab." Tesis Sekolah Pascasarjana UIN Syarif Hidayatullah, 2009.

al-Ṣâbûnî, Muhammad 'Ali. al-Tibyân fî Ulûm al-Qur'ân. Beirut: 'Âlam alKutub, cetakan pertama, 1985.

al-Ṣâlih, Subhi. Mabâhith fî Ulûm al-Qur'ân. Cetakan ke-17. Beirut: Dâr al-'Ilm li al-Malâyîn, 1988.

Safadi, Yasin Hamid. Islamic Calligraphy. London: Themes and Hudson, 1978.

Shihab, M. Quraish. Mukjizat Al-Qur'an. Bandung: Mizan, 1998. 
Sirojuddin AR., D. Seni Kaligrafi Islam. Jakarta: PT. Multi Kreasi Singgasana, 1992.

Subhani, Ja'far. al-Risalah: Sejarah Kehidupan Rasulullah. Terj. Muhammad Hasyim dan Meth Kierana, cetakan ke-1. Jakarta: Lentera, 1996.

Teeuw, A. Indonesia: Antara Kelisanan dan Keberaksaraan. Jakarta: Pustaka Jaya, 1994.

Watt, W. Montgomery. Pengantar Studi Al-Qur'an: Penyempurnaan atas Karya Richard Bell. Terj. Taufik Adnan Amal, cetakan I. Jakarta: CV. Rajawali, 1991.

Watt, W. Montgomery. Richard Bell: Pengantar al-Qur'an. Terj. Lillian D. Tedjasudhana. Jakarta: INIS, 1998.

Wawancara dengan Agus BM (9 September 2011.

Wawancara dengan M. Aziz (12 Nopember 2011.

Wawancara dengan M.Jamil (Oktober 2011..

Wawancara dengan N. Nur Cholis (3 Desember 2011.

Al-Zarkashî. al-Burhân fî' Ulûm al-Qur'ân. Kairo: Dâr al-Hadîth, 2006.

al-Zarqânî, Muhammad 'Abdul Aẓ̂m. Manâhil al- 'Irfân fî Ulûm al-Qur'ân. Jilid 1. Beirut: Dâr al-Kutub al-'Ilmiyah, 1996. 